\title{
PENGARUH METODE PEMBELAJARAN DAN PENGETAHUAN BERWAWASAN LINGKUNGAN TERHADAP KECERDASAN NATURALIS ANAK USIA DINI 5-6 TAHUN
}

\author{
Mohamad Syarif Sumantri* \\ Diana*
}

\begin{abstract}
The purpose of this research was to obtain the data on the effects of instructional methods and insightful knowledge of environment towards the naturalistic intelligence of the children at the age of five and six years. Employing experimental methods, this research was carried out in Natural Ar-Ridho Kindergarten, Semarang. The results of this research show (1) naturalistic intelligence of the children with hands-on learning method is higher than of those with storytelling method, (2)naturalistic intelligence of the children having insightful knowledge of environment and treated with hands-on method of learning is higher than those treated with storytelling method, (3) naturalistic intelligence of the children having low insightful knowledge of environment and treated with storytelling method is higher than those treated with hands-on learning methods and (4) there is interaction between instructional method and insightful knowledge of environment towards the naturalistic intelligence of the children at the age of five and six years
\end{abstract}

Keywords : learning methods, insightful knowledge, naturalistic intelligence

\begin{abstract}
Abstrak
Tujuan penelitian ini adalah untuk mendapatkan data tentang pengaruh metode pembelajaran dan pengetahuan berwawasan lingkungan terhadap kecerdasan naturalis anak usia 5-6 tahun. Penelitian ini dilaksanakan pada semester genap tahun ajaran 2010-2011, di TK Alam Ar-Ridho Semarang. Penelitian ini menggunakan metode eksperimen. Hasil penelitian ini menunjukkan (1) kecerdasan naturalis kelompok anak yang diberikan metode pembelajaran praktik langsung lebih tinggi daripada anak yang diberikan metode pembelajaran bercerita, (2) kecerdasan naturalis kelompok anak yang diberikan metode pembelajaran praktik langsung pada anak yang memiliki pengetahuan berwawasan lingkungan lebih tinggi daripada kelompok anak yang diberikan metode pembelajaran bercerita, (3) kecerdasan naturalis kelompok anak yang diberikan metode pembelajaran bercerita pada anak yang memiliki pengetahuan berwawasan lingkungan rendah lebih tinggi dari pada kelompok anak yang diberikan metode pembelajaran praktik langsung, dan (4) terdapat interaksi antara metode pembelajaran dan pengetahuan berwawasan lingkungan terhadap kecerdasan naturalis anak usia 5-6 tahun.
\end{abstract}

Kata-kata Kunci: metode pembelajaran, pengetahuan berwawasan lingkungan, kecerdasan naturalis

\section{PENDAHULUAN}

\section{Latar Belakang Masalah}

Wajah dunia, wajah negara, dan wajah kota sekarang ini telah mengalami sebuah perubahan yang amat besar. Bumi yang dulunya ramah sekarang sudah mulai tidak ramah lagi terhadap manusia. Perlakuan

\footnotetext{
* Dosen Pascasarjana Jurusan Pendidikan Dasar Universitas Negeri Jakarta

${ }^{*}$ Dosen Program Sarjana PG-PAUD Universitas Negeri Semarang
}

manusia yang membuat wajah-wajah yang dulunya rindang, teduh, dan nyaman untuk menikmati kehidupan telah mengubahnya secara total. Banyaknya gedung-gedung indah menghiasi kota, perumahanperumahan megah, telah menyingkirkan tanah dan tanaman sebagai pusat kehidupan dan bermain anak. Bahkan penambahan onggokan-onggokan sampah di mana-mana, karena tidak adanya tempat serta lahan untuk mendaur ulang limbah-limbah produksi dari hasil 
buah tangan manusia.

Perilaku manusia sebagai bentuk implementasi pengetahuannya tidak lagi mementingkan kelangsungan kehidupan bagi generasi penerus untuk dapat menikmati lingkungan yang sehat, aman, dan nyaman sehingga kehilangan kehidupan yang sehat bagi anakanak usia dini yang sangat membutuhkan tempat yang nyaman untuk bermain.

Berdasarkan Surat Keputusan Menteri Pendidikan dan Kebudayaan No. 008C/U/1975 menetapkan bahwa Pendidikan Kependudukan dan Lingkungan Hidup (PKLH) mulai diterapkan di Sekolah Dasar (SD) (Neomatahari, 2010).

Pada dasarnya, pendidikan lingkungan hidup tidak ditujukan untuk anak prasekolah, namun diharapkan sejak dini anak sudah ditumbuhkan dengan pengetahuan berwawasan lingkungan sebelum memasuki pendidikan dasar, sehingga pendidikan lingkungan hidup nantinya dapat menumbuhkan sikap baru terhadap komponen seperti air, udara, hewan, dan tumbuhan, serta mencapai tujuan pendidikan lingkungan hidup yaitu "mengantarkan kaum muda untuk memahami alam dengan penuh kasih sayang dan hormat terhadap sesama makhluk ciptaan Tuhan".

Metode pembelajaran tentang baik dan buruk, boleh dan tidak boleh dilakukan ketika seseorang berada dalam sebuah lingkungan kehidupan bersama, menjadi sangat penting. Metode pembelajaran berisi moral tidak hanya berisikan etika terhadap sesama manusia saja, melainkan juga pengetahuan tentang etika terhadap lingkungannya. Metode pembelajaran yang terkait diterapkan melalui kegiatan pembiasaan pada anak sangatlah bermakna. Melalui metode pembelajaran yang tepat berisi tentang pengetahuan berwawasan lingkungan, menjadikan anak dapat mencintai, dan menjaga lingkungan dengan sepenuh hati. Anak akan selalu melakukan hal-hal yang baik untuk lingkungannya dan dapat melakukan sesuatu yang bermanfaat bagi lingkungannya. Hal ini semestinya ditanamkan tidak hanya untuk sekolah dasar namun sejak usia dini, khususnya di Taman Kanak-kanak (TK).

TKAlam Ar-Ridho merupakan sebuah lembaga pendidikan yang memfasilitasi kegiatan pembelajaran untuk anak usia 4-6 tahun. TK ini memiliki visi dan misi yaitu menjadikan sekolah yang selalu berinovatif dan kreasi untuk menyempurnakan sistem, metode, dan praktik pendidikan, misinya adalah mendidik siswa menjadi generasi unggul (khoiru ummah) yang mengarahkan pertumbuhan dan perkembangan anak dengan mengoptimalkan lingkungan sebagai sumber belajar anak. Sebagai sekolah alam yang semestinya menjadikan alam sebagai sarana dan media pada pembelajaran, TK merupakan sumber pengetahuan bagi anak. Sekolah ini secara geografis dan penataan lingkungannya sudah baik sebagai sekolah dengan pendekatan pendidikan melalui alam. Namun, TK ini kurang memanfaatkan lingkungan sebagai sumber belajar secara efektif. Kepedulian anak tentang lingkungan juga kurang, sehingga anak kurang memiliki sensitivitas terhadap lingkungan. Pada anak belum terbentuk sikap karakter bersih seperti kebiasaan membuang sampah pada tempatnya.

Hal ini juga dibuktikan pula dengan masih kurangnya usaha guru untuk menumbuhkan kecerdasan naturalis yang terkait dengan lingkungan, misalnya menyediakan tempat sampah di setiap sudut sekolah, memberikan ruang, tempat atau lahan untuk anak bercocok tanam, membiasakan anak untuk menyimpan barang-barang bekas seperti bungkus makanan, botol bekas, dan kotak susu yang dapat dimanfaatkan anak dalam kegiatan pembelajaran, serta kurangnya pendidik atau guru mengembangkan kecerdasan naturalis melalui metode pembelajaran yang mengaitkan anak dengan lingkungan sekitar, sehingga kecerdasan naturalis anak kurang dapat dikembangkan secara optimal, dan anak kurang memiliki pengetahuan yang berwawasan lingkungan.

Melalui pemilihan metode pembelajaran yang sesuai dapat mengembangkan kecerdasan naturalis anak dan menumbuhkan pengetahuan yang berwawasan lingkungan pada anak.

Adapun metode pembelajaran yang dapat disesuaikan dengan kecerdasan naturalis dan akan menumbuhkan pengetahuan berwawasan lingkungan pada anak usia dini, khususnya di TK, antara lain melalui metode praktik langsung dan bercerita. Kedua metode ini diminati oleh anak, karena sangat menyukai cerita dan senang melakukan kegiatan dengan pengamatan atau kunjungan langsung.

Melalui metode pembelajaran praktik langsung dan bercerita diharapkan pengetahuan yang diterima anak dapat menyentuh dan terinternalisasi dalam diri anak, sehingga kecerdasan naturalis dan pengetahuan berwawasan terhadap lingkungan pada anak dapat berkembang secara optimal. Dua metode pembelajaran moral khususnya pengembangan kecerdasan naturalistik anak usia dini 5-6 tahun ini diharapkan akan memberikan perubahan baik pada anak untuk memiliki pengetahuan berwawasan lingkungan tinggi maupun rendah.

\section{Identifikasi Masalah}

Berdasarkan latar belakang masalah yang dipaparkan di atas, maka permasalahan dapat diidentifikasi, sebagai berikut. 
1. Masih banyaknya lembaga pendidikan PAUD, khususnya TKAr-Ridho lebih menekankan pengembangan aspek kognitif dan bahasa anak saja dalam setiap kegiatan pembelajaran.

2. Kurangnya usaha guru untuk menanamkan pembelajaran moral yang terkait dengan pengetahuan berwawasan lingkungan pada anak.

3. Kurangnya fasilitas sekolah yang dapat mendukung pembelajaran moral dan kecerdasan naturalis, sehingga anak dapat memiliki pengetahuan berwawasan lingkungan.

4. Ketidakmampuan guru untuk dapat mengaitkan pembelajaran dengan mengembangkan metode pembelajaran dan pengetahuan berwawasan lingkungan, sehingga anak mampu mengembangkan kecerdasan naturalis dalam setiap kegiatan pembelajaran.

\section{Pembatasan Masalah}

Penelitian ini dibatasi pada metode pembelajaran dan pengetahuan berwawasan lingkungan terhadap kecerdasan naturalis anak usia dini 5-6 tahun di TK B (eksperimen di TK Alam Ar-Ridho, Tembalang Semarang).

Metode pembelajaran adalah upaya yang digunakan guru dalam menjalankan fungsinya merupakan alat untuk mencapai tujuan pembelajaran. Metode bercerita merupakan sebuah upaya guru dalam menyampaikan materi pembelajaran pada anak melalui cerita, baik melalui buku cerita ataupun media bergambar. Sedangkan, metode praktik langsung adalah upaya guru dalam memberikan materi pembelajaran dalam bentuk anak mempraktikkan secara langsung materi-materi ajar.

Kecerdasan naturalis adalah kemampuan dan keterampilan dalam mengobservasi pola-pola alam dan memahami sistem alamiah dan sistem buatan manusia. Pengetahuan berwawasan lingkungan adalah kemam- puan pemahaman bahan-bahan yang pernah dipelajari berhubungan dengan topik lingkungan serta berkaitan dengan perilaku yang dimunculkan sebagai implementasi pengetahuan yang didapat dalam hal menjaga kebersihan, memanfaatkan lingkungan secara efisien, serta mengatur dan memelihara lingkungan sehingga nyaman dan asri.

Penelitian ini dibatasi pada metode pembelajaran melalui praktik langsung dan bercerita pada anak-anak yang memiliki pengetahuan berwawasan lingkungan yang tinggi dan rendah dalam menumbuhkan dan mengembangkan kecerdasan naturalis pada anak usia 5-6 tahun di kelompok B.

\section{Perumusan Masalah}

Berdasarkan latar belakang, identifikasi, dan pembatasan masalah yang digambarkan di atas, maka masalah dalam penelitian ini dapat dirumuskan, sebagai berikut.

1. Apakah terdapat perbedaan kecerdasan naturalis anak usia 5-6 tahun yang diberikan metode pembelajaran bercerita dengan anak yang diberikan metode pembelajaran praktik langsung?

2. Apakah terdapat perbedaan kecerdasan naturalis anak usia 5-6 tahun yang memiliki pengetahuan berwawasan lingkungan tinggi dengan menggunakan metode pembelajaran bercerita dan praktik langsung?

3. Apakah terdapat perbedaan kecerdasan naturalis anak usia 5-6 tahun yang memiliki pengetahuan berwawasan lingkungan yang rendah dengan menggunakan metode pembelajaran bercerita dan praktik langsung?

4. Apakah terdapat pengaruh interaksi antara metode pembelajaran bercerita dan praktik langsung, pengetahuan berwawasan lingkungan terhadap kecerdasan anak usia 5-6 tahun?

\section{KAJIAN TEORETIS}

\section{Hakikat Kecerdasan Naturalis}

Kecerdasan adalah kombinasi sifat-sifat manusia yang mencakup kemampuan untuk memahami hal-hal yang kompleks dan saling berhubungan semua proses yang terlibat dalam berpikir abstrak, kemampuan menemukan, penyesuaian dalam pemecahan masalah dan kemampuan untuk memperoleh kemampuan yang baru termasuk dalam kecerdasan (Semiawan \& Djeniah, 2002: 11-13).

$\mathrm{Hal}$ ini terkait dengan struktur otak dan berfungsinya belahan otak kanan dan kiri. Hal ini juga sejalan dengan pendapat yang mengemukakan bahwa kecerdasan merupakan kemampuan berpikir secara abstrak dan belajar dari pengalaman (Cooper \& Sawat, 1998: 416). Kecerdasan merupakan kemampuan untuk beradaptasi dengan situasi baru, belajar dari kesalahan di masa lampau dan mengkreasikan pola pikir baru (Sprinthall \& Sprinthall, 1990: 431-432).

Menurut Stenberg dalam Good \& Brophy (1990: 594-595), kecerdasan adalah daya baru menyesuaikan diri dengan alat-alat berpikir menurut tujuannya. Stenberg menitikberatkan kecerdasan pada kemampuan menyesuaikan diri (adjusment) terhadap masalah yang dihadapi. 
Lebih lanjut, Mc Nerney menyatakan bahwa kecerdasan mencakup kemampuan manusia akan tiga komponen, yaitu (1) kecerdasan kompensial (Compential Intelegency) yaitu kemampuan untuk berpikir, merencanakan, dan memonitor proses koqnitif; (2) kecerdasan eksperensial (Experential Intelegency) yaitu kemampuan untuk memformulasikan ide-ide baru dalam memecahkan masalah; dan (3) kecerdasan kontekstual (Contextual Intelegency) yaitu kemampuan untuk beradaptasi dalam menanggapi suatu peluang/ kesempatan secara optimis (Nerney \& Nerney, 1998: $49-50)$.

Kecerdasan menurut Whiterington (2002: 24) adalah suatu perbuatan yang dilakukan secara efisien. Suatu aktivitas dikatakan efisien apabila secara cepat, mudah, dan tepat. Faktor kecepatan yaitu berbuat cepat dalam merespon suatu stimulus. Faktor kemudahan adalah kemampuan menyelesaikan suatu persoalan dengan mudah, sedangkan faktor ketepatan adalah kemampuan menyelesaikan masalah secara lengkap dan sesuai (Whiterington, 2002: 24).

Pendapat-pendapat di atas dapat disimpulkan bahwa kecerdasan adalah kombinasi sifat-sifat manusia yang mencakup kecakapan dalam berpikir, merencanakan, memformulasikan ide-ide baru dalam memecahkan masalah, serta kemampuan dalam beradaptasi menghadapi peluang yang ada.

\section{Kecerdasan Naturalis}

Menurut Gardner (dalam Armstrong, 2002: 26), seseorang yang memiliki kecerdasan naturalis tinggi adalah seseorang yang menunjukkan kemahiran dalam mengenali dan mengklasifikasikan banyak spesies flora dan fauna dalam lingkungannya. Menurut Christison (1999), kecerdasan naturalis adalah kemampuan untuk mengenal dan mengklasifikasikan tanaman, barang tambang, dan hewan.

Pada dunia nyata, seorang naturalis memiliki kemahiran dalam berkebun, menggarap taman yang indah, memelihara binatang, serta memiliki perhatian yang lebih dalam. Penyelamatan lingkungan seorang naturalis biasanya telah memperlihatkan bakatnya sejak kecil/masa kanak-kanak. Menurut Ross dan Nicholl (2002: 260), seseorang yang memiliki kecerdasan naturalis tinggi adalah seorang yang senang memelihara binatang, dapat mengenali dan menamai banyak jenis tanaman, mempunyai minat dan pengetahuan yang baik tentang bagaimana tubuh bekerja, dapat membaca tanda-tanda cuaca, mempunyai pemahaman dan minat pada isu-isu lingkungan global dan berpandangan bahwa pelestarian sumber daya dan pertumbuhan yang berkelanjutan meruapakan keharusan.

Menurut DePorter dkk, (2002: 90 - 100), seseorang yang memiliki kecerdasan naturalis tinggi selalu berpikir dalam acuan alam. Kecerdasan naturalis menyangkut perhatian seseorang dengan alam. Hal ini dapat dilihat dari kemampuannya melihat hubungan dan pola dalam dunia alamiah, mengidentifikasi, dan berinteraksi dengan proses alam. Menurut Cripps dan Nguyen (2004) siswa-siswa yang berkompeten dalam kecerdasan naturalis merupakan pencinta alam. Siswasiswa ini lebih suka mengumpulkan bebatuan/bunga daripada mengerjakan tugas menulisnya. Jika diberikan tugas sekolah yang melibatkan bunga-bungaan/ tanaman juga hewan, maka siswa-siswa ini akan termotivasi dengan lebih baik.

Menurut Anderson (2002: 144), orang yang memiliki kecerdasan naturalis tinggi akan dengan mudah memiliki motivasi yang kuat untuk menjadi seorang ahli ekologi, ahli botani, ahli zoologi atau ahli geologi. Hal ini disebabkan karena seorang naturalis memiliki kepedulian dan kepekaan yang kuat akan lingkungan alam. Collegiate (2003: 1) mendefinisikan kecerdasan naturalis sebagai kemampuan individu dalam membedakan berbagai komponen alam serta memiliki kepekaan dalam melihat gejala-gejala alam. Untuk mengukur kecerdasan naturalis siswa dapat dilakukan dengan memberikan bacaan ilmiah tentang lingkungan, lalu siswa diminta untuk melakukan observasi. Cara lain adalah mengajak siswa belajar di lingkungan alam serta menjelaskan berbagai jenis hewan dan tumbuhan yang ditemukan di lapangan. Setelah itu, siswa diminta mengaitkan komponen satu dengan yang lain.

Kecerdasan naturalis berhubungan dengan kemampuan individu untuk mengenal tumbuhan, hewan, dan komponen alam lainnya seperti awan, gunung, ekosistem, dan segala yang berhubungan dengan lingkungan alam. Orang yang memiliki kecerdasan naturalis tinggi mempunyai ciri memilki kemampuan untuk mengenal flora dan fauna, dapat membedakan berbagai komponen lingkungan alam, menggunakan keahliannya dalam hal berkebun, naik gunung, menyukai ilmu biologi murni, bercita-cita menjadi ahli botani, zoologi, biologi, konservasi, menyukai hewan peliharaan, dapat menyebut berbagai nama tumbuhan dan bunga-bungaan, menyukai dan mengenal lebih jauh tentang organ-organ tubuh, menyukai pertanaman, serta memiliki perhatian untuk memahami masalah lingkungan secara global (Collegiate, 2003: 1)

\section{Pengetahuan Berwawasan Lingkungan}

Menurut Soekamto (1982: 6), pengetahuan adalah kesan di dalam pikiran manusia sebagai hasil penggunaan pancainderanya, yang berbeda sekali dengan kepercayaan (believe), takhayul (supersititions), dan penerangan yang keliru (misinformations). Ini berarti bahwa pengetahuan manusia diperoleh dengan cara 
menggunakan panca indera dengan melakukan interaksi dengan alam sekitar dan lingkungan sosialnya. Dengan demikian, pengetahuan itu merupakan hasil proses berpikir manusia yang diperoleh dari alam lingkungannya dan kehidupan sosial masyarakatnya.

IImu pengetahuan adalah pengetahuan (knowledge) yang tersusun sistematis dengan menggunakan kekuatan pemikiran dan pengetahuan selalu dapat diperiksa dan ditelaah (dikontrol) dengan kritis oleh setiap orang lain yang ingin mengetahuinya (Soekamto, 1982: 6). Selanjutnya dikemukakan Haryanto (1997: 50), pengetahuan (knowledge) diartikan sebagai kemampuan untuk mengingat bahan-bahan yang pernah dipelajari termasuk didalamnya kemampuan mengingat kembali berbagai hal mulai dari fakta yang sangat khusus sampai kepada teori-teori yang rumit.

Lingkungan hidup atau lingkungan adalah segala benda, kondisi, keadaan, dan pengaruh yang terdapat dalam ruang yang ditempati dan mempengaruhi hal yang hidup termasuk kehidupan manusia (Salim, 1993: 32). Sedangkan menurut Gottlieb (1995: 1), lingkungan hidup merupakan semua keadaan yang diperoleh dalam kehidupan dan perilaku manusia.

Menurut Soeryani (2002: 17 - 18), lingkungan hidup manusia terdiri atas lingkungan hidup alam, lingkungan hidup buatan atau binaan manusia, serta lingkungan hidup sosial. Lingkungan hidup alam terdiri atas komponen fisik (sekumpulan pengada ragawi $=$ abiota), komponen hayati (sekumpulan pengada insan = biota), serta interaksi antarkomponen-komponen tersebut. Manusia merupakan bagian dari lingkungan hayati. Lingkungan hidup alam juga berarti lingkungan hidup yang telah ada di alam tanpa memperoleh gangguan atau dimodifikasi oleh manusia. Lingkungan hidup buatan atau binaan adalah suatu lingkungan yang dibentuk manusia dengan menerapkan ilmu pengetahuan, teknologi, dan seni. Lingkungan hidup binaan terbentuk berkat adanya kemampuan manusia yang lebih tinggi dibandingkan dengan kemampuan komponen biotik lainnya. Manusia memiliki kemampuan berpikir, bernalar, berorganisasi, serta kemajuan dalam mengembangkan ilmu pengetahuan dan teknologi serta budaya yang membentuknya.

Dari uraian di atas, maka yang dimaksud pengetahuan berwawasan lingkungan dalam penelitian ini adalah sebuah kemampuan untuk mengingat bahanbahan yang pernah dipelajari termasuk didalamnya yang berhubungan dengan lingkungan. Selain itu juga, berkaitan dengan perilaku yang dimunculkan sebagai implementasi pengetahuan yang didapat dalam hal menjaga kebersihan, memanfaatkan lingkungan secara efisien, serta mengatur dan memelihara lingkungan sehingga nyaman dan asri.

\section{Metode Pembelajaran}

Keberadaan metode sangatlah penting dalam pendidikan, di mana dengan adanya metode dapat mempermudah pencapaian tujuan yang diharapkan. Dengan demikian, seorang guru mutlak memiliki metode dalam mentransfer ilmu kepada siswanya. Metode adalah prosedur yang disusun secara teratur dan logis serta dituangkan dalam suatu rencana kegiatan untuk mencapai tujuan (Sudjana, 1999: 7 10). Unsur-unsur yang mencakup metode meliputi unsur prosedur, sistematik, logis, terencana, dan kegiatan yang mencapai tujuan. Demikian pula, Soekamto dan Saripusin (1997: 78-79) menyatakan bahwa metode adalah suatu prosedur yang sistematis dalam mengorganisasikan suatu kegiatan untuk mencapai suatu tujuan.

\section{Bercerita}

Menurut Semiawan (2002: 33 - 34), cerita merupakan wahana yang ampuh untuk mewujudkan pemahaman (verstehen) anak dan penghayatan pengalaman (penetrate into) anak. Dengan demikian, melalui cerita terjadi pertemuan antara emosi, pemahaman, dan keterlibatan mental antara yang bercerita dengan anak. Keasyikan dalam menyelami materi cerita dapat memasuki dunia minat (center of interest). Menurut Sawyer dan Corner (1991: 1 - 6), cerita memiliki banyak manfaat bagi perkembangan anak. Manfaat tersebut antara lain (1) belajar mengenal dunia, (2) pembentukan sifat positif seperti percaya diri, toleransi antarsesama makhluk, (3) menumbuhkan rasa ingin tahu, dan (4) belajar berhubungan antarmanusia.

Cerita adalah suatu karya sastra yang digambarkan secara verbal yang dapat memacu anak untuk berkomunikasi, berfantasi atau berimajinasi, serta dapat mengembangkan kecerdasan emosional, sikap, dan perilaku positif dengan lingkungan dan mengembangkan kognisinya. Adapun kelebihan dan kelemahan dari metode bercerita, berdasarkan kesimpulan di atas, diantaranya kelebihan yaitu (a) mengembangkan daya fantasi dan imajinasi pada anak, (b) mengembangkan kemampuan kognisi anak, (c) mengasah kecerdasan emosional anak, (d) menumbuhkan minat baca pada anak, (e) mengembangkan kepedulian terhadap lingkungan dan sesama, dan (f) sebagai media pembelajaran. Selain itu, kelemahan dari metode bercerita diantaranya (a) kemampuan mendengar anak lebih banyak digunakan dibandingkan visualnya; (b) bila bercerita terlalu lama akan cepat membuat anak bosan; (c) anak lebih cenderung aktif, guru yang lebih banyak bertanya; dan (d) bagi guru yang kurang ekspresif bercerita, akan terkesan kurang menarik bagi anak dan ceritanya menjadi tidak bermakna. 


\section{Praktik Langsung}

Praktik langsung atau pengajaran langsung (direct instruction) adalah sebuah metode pembelajaran yang mempelajari informasi atau tindakan yang diciptakan oleh orang lain, tetapi tidak membangun pengetahuan untuk dirinya sendiri. Melalui kegiatan praktik langsung diharapkan anak mendapatkan pengalaman melalui interaksi langsung dengan objek secara langsung atau nyata (Sujiono, 2004: 5.12).

Menurut Dale bahwa pembelajaran melalui praktik langsung akan memberikan pengalaman yang besar. Kemampuan anak untuk mengingat dengan baik tentang apa yang telah dipelajarinya ketika anak mendapatkan pengalaman langsung, anak tidak hanya mendengar, melihat tetapi juga terjun langsung dalam proses pembelajaran. Dale juga mengembangkan pemikiran bahwa masing-masing pembelajaran memberikan pengaruh besar dalam proses mengingat, hal ini digambarkan dalam sebuah kerucut piramida pengalaman belajar.

Dale juga menjelaskan bahwa pemberian metode pembelajaran dengan menggunakan model, melakukan simulasi, serta melakukan praktik langsung akan memberikan banyak pengalaman belajar bagi anak. Anak tidak hanya belajar menemukan sesuatu, tetapi juga memiliki kemampuan untuk menganalisis apa yang telah ditemukannya. Kemampuan ini hanya akan diperoleh jika anak dapat berinteraksi langsung dengan lingkungannya.

Metode praktik langsung adalah suatu upaya mengembangkan pengalaman belajar anak secara konkret, langsung dan nyata. Melalui metode ini semua, kemampuan anak dapat dikembangkan tidak hanya secara auditori dan visualnya saja melainkan juga kemampuan fisik motorik terlatih untuk melakukan tugas-tugas secara langsung. Adapun kelebihan dan kelemahan dari metode praktik langsung berdasarkan kesimpulan di atas, diantaranya kelebihan; (a) membuat pembelajaran menjadi lebih konkret; (b) anak lebih mudah memahami apa yang dipelajarinya secara konkret; (c) proses pembelajarannya menjadi lebih menarik; (d) merangsang kreativitas anak dengan memanfaatkan lingkungan sebagai sumber pembelajaran; dan (e) siswa dirangsang untuk aktif mengamati, menyesuaikan antara teori dengan kenyataan, dan melakukannya sendiri. Kelemahan: (a) memerlukan keterampilan guru secara khusus untuk dapat mempraktikkan apa yang akan dipelajari oleh anak, kalau tidak maka kegiatan pembelajarannya akan tidak efektif; (b) memerlukan fasilitas dan biaya yang cukup banyak; dan (c) memerlukan kesiapan dan perencanaan yang sangat matang dan memerlukan waktu yang cukup panjang.

\section{Karakteristik Anak Usia 5 - 6 tahun}

Anak adalah sosok pribadi yang sangat unik berbeda satu sama lain. Anak memiliki ciri atau karakteristik yang berbeda dari setiap usia perkembangannya. Pada hal ini, anak usia 5-6 tahun adalah yang telah menapaki dunia prasekolah sebagai sarana mengembangkan seluruh potensi yang ada dalam dirinya. Ketika belajar untuk mengenal dunianya, ada hal-hal yang menjadi perhatian dalam menstimulasinya. Salah satunya adalah dilandasi oleh karakteristik yang dimiliki oleh anak usia 5-6 tahun.

Karakteristik perkembangan yang sangat menonjol berkaitan dengan penelitian ini yaitu karakteristik kognitif anak usia 5-6 tahun. Piaget mengemukakan bahwa anak usia 5-6 tahun berada pada fase Praoperasional, rentang fase ini adalah 2-7 tahun yang didalamnya termasuk anak usia 5-6 tahun. Fase ini merupakan masa permulaan anak untuk membangun kemampuannya dalam menyusun pikirannya dalam hal ini pengetahuan. Oleh sebab itu, cara berpikir anak belum stabil dan belum terorganisir secara baik (Sujiono, 2009: 120).

Pada usia ini, anak sudah dapat mengklasifikasikan objek sesuai dengan kelompoknya. Menurut Piaget (dalam Sujiono, 2009: 120), pengalaman belajar anak pada usia ini akan lebih banyak didapat dengan cara bermain, melakukan percobaan dengan objek nyata, dan melalui pengamatan konkret. Anak memiliki kesempatan untuk mengkreasikan dan memanipulasi objek atau ide.

Cara anak membangun pengetahuan pada usia 5-6 tahun ini adalah melalui interaksi sosial dan interaksi pengetahuan fisik. Melalui interaksi sosial, anak mengetahui sesuatu dari manusia lain, ketika meneliti atau melihat sesuatu, anak tersebut akan tahu tentang objek tersebut jika diberitahukan oleh pihak lain. Melalui pengetahuan fisik, yaitu mengetahui sifat fisik dari suatu benda. Pengetahuan ini diperoleh dengan menjelajahi dunia yang bersifat fisik, melalui kegiatan tersebut anak akan belajar tentang bentuk, warna, rasa, dan perubahan yang terjadi di lingkungan. Konsep tersebut didapat dari pemahaman anak terhadap lingkungan di mana anak berinteraksi langsung.

Selain itu juga, pada usia 5-6 tahun ini, anak masih berpikir secara simbolik, yaitu kemampuan berpikir tentang objek dan peristiwa secara abstrak. Anak sudah dapat menggambarkan objek yang tidak ada dihadapannya. Kemampuan berpikir simbolik ditambah dengan perkembangan kemampuan bahasa dan fantasi sehingga anak mempunyai dimensi baru dalam bermain. Anak dapat menggunakan kata-katanya untuk menandai suatu objek dan membuat substitusi dari objek tersebut. 
Berdasarkan pendapat di atas dapat disimpulkan bahwa anak usia 5-6 tahun memiliki kemampuan untuk berpikir secara praoperasional, di mana anak masih memerlukan objek dan berinteraksi langsung untuk membangun pengetahuannya. Pada tahap ini juga kemampuan fantasi dan imajinasi anak masih berkembang sehingga memiliki dimensi baru dalam bermain. Perkembangan kognitif sejalan dengan perkembangan bahasa anak, sehingga dengan berkembangnya kemampuan kognitif anak maka akan berkembang pula kemampuan berbahasanya. Kemampuan anak untuk mengetahui tentang apa yang ada disekitarnya dapat ditandai melalui ungkapan katakata tentang apa yang ada atau apa yang terjadi di sekitarnya melalui kata-kata.

\section{METODOLOGI PENELITIAN}

Penelitian dilakukan dengan menggunakan metode kuasi eksperimen dengan desain faktorial $2 \mathrm{X}$ 2 dalam penelitian ini terdapat tiga variabel penelitian, yaitu satu variabel terikat dan dua variabel bebas. Sebagai variabel terikat (dependent variabel) adalah kecerdasan naturalis $(\mathrm{Y})$ dan dua variabel bebas (independent variabel) adalah metode pembelajaran sebagai variabel eksperiemen $(A)$ dan pengetahuan berwawasan lingkungan $(B)$ sebagai atribut.

Variabel perlakuan pembelajaran (A) dibedakan menjadi dua, yaitu (A1) metode pembelajaran melalui praktik langsung dan (A2) metode pembelajaran melalui bercerita. Variabel atribut kecerdasan (B) dibedakan menjadi dua jenis, yaitu pengetahuan berwawasan lingkungan tinggi $\left(B_{1}\right)$ dan pengetahuan berwawasan lingkungan yang rendah $\left(B_{2}\right)$. Konstelasi variabel penelitian dapat dilihat pada rancangan faktorial $2 \times 2$.

Penelitian dilakukan di TK Alam Al Ridho, Tembalang, Semarang. Penelitian dilaksanakan pada semester 2 (genap) pada tahun akademik 2010/2011.
Penentuan waktu penelitian memperhatikan prinsip eksperimen, yaitu perlakuan (treatment) dapat dihentikan bila diketahui telah terjadi perubahan tingkah laku pada subjek eksperimen. Perubahan tingkah laku ini dalam hal adanya peningkatan skor kecerdasan naturalis anak. Gay (1996: 112) mengemukakan bahwa perubahan tingkah laku akan terjadi apabila diberikan perlakuan dalam periode waktu tertentu. Berdasarkan pendapat tersebut bahwa eksperimen dilakukan dalam periode waktu 2 bulan selama 12 kali pertemuan.

Tabel 1. Desain Penelitian Faktorial $2 \times 2$

\begin{tabular}{|l|l|l|}
\hline \multirow{2}{*}{$\begin{array}{l}\text { Variabel Eksperimen } \\
\text { Metode Pembelajaran }\end{array}$} & \multicolumn{2}{|c|}{ Metode Pembelajaran } \\
\cline { 2 - 3 } $\begin{array}{l}\text { Variabel } \\
\text { Pengetahuan } \\
\text { Berwawasan } \\
\text { Lingkungan }\end{array}$ & $\begin{array}{c}\text { Metode } \\
\text { Pembelajaran } \\
\text { praktik } \\
\text { langsung } \\
\left(A_{1}\right)\end{array}$ & $\begin{array}{c}\text { Metode } \\
\text { Pembelajaran } \\
\text { bercerita } \\
\left(A_{2}\right)\end{array}$ \\
\hline Tinggi $\left(B_{1}\right)$ & $A_{1} B_{1}$ & $A_{2} B_{1}$ \\
\hline Rendah $\left(B_{2}\right)$ & $A_{1} B_{2}$ & $A_{2} B_{2}$ \\
\hline
\end{tabular}

\section{HASIL PENELITIAN}

Data yang telah terkumpul melalui penelitian ini ditabulasikan sesuai dengan keperluan analisis data yang tercantum dalam rancangan penelitian yang bertujuan untuk menunjukkan gambaran umum mengenai penyebaran atau distribusi data.

Telah dijelaskan bahwa penelitian ini adalah penelitian eksperimen yang menggunakan rancangan analisis faktorial $2 \times 2$ sehingga berdasarkan rancangan tersebut maka deskripsi data yang akan disajikan di sini yaitu (1) kecerdasan naturalis anak yang diberikan metode pembelajaran dengan praktik langsung $\left(A_{1}\right)$; $(2)$ kecerdasan naturalis anak yang diberikan metode pembelajaran dengan bercerita $\left(A_{2}\right)$; (3) kecerdasan naturalis anak yang memiliki pengetahuan berwawasan lingkungan yang tinggi $\left(B_{1}\right)$; $(4)$ kecerdasan naturalis anak yang memiliki pengetahuan berwawasan lingkungan yang rendah $\left(B_{2}\right) ;(5)$ kecerdasan naturalis anak yang diberikan metode pembelajaran praktik langsung dan memiliki pengetahuan berwawasan lingkungan yang tinggi $\left(A_{1} B_{1}\right) ;(6)$ kecerdasan naturalis anak yang diberikan metode pembelajaran praktik langsung dan memiliki pengetahuan berwawasan lingkungan yang rendah $\left(A_{1} B_{2}\right) ;(7)$ kecerdasan naturalis anak yang diberikan metode pembelajaran bercerita dan memiliki pengetahuan berwawasan lingkungan yang tinggi $\left(\mathrm{A}_{2} \mathrm{~B}_{1}\right)$; serta (8) kecerdasan naturalis anak yang diberikan metode pembelajaran bercerita dan memiliki pengetahuan berwawasan lingkungan yang rendah $\left(A_{2} B_{2}\right)$. 
Tabel 2. Deskripsi Data

\begin{tabular}{|c|c|c|c|}
\hline $\begin{array}{l}\text { Metode } \\
\text { Pembelajaran } \\
\text { Pengetahuan } \\
\text { Berwawasan } \\
\text { Lingkungan }\end{array}$ & $\begin{array}{c}\left(\mathbf{A}_{1}\right) \\
\text { Metode } \\
\text { Pembelajaran } \\
\text { Praktik } \\
\text { Langsung }\end{array}$ & $\begin{array}{c}\left(\mathbf{A}_{2}\right) \\
\text { Metode } \\
\text { Pembelajaran } \\
\text { Bercerita }\end{array}$ & $\underset{\text { Baris }}{\Sigma}$ \\
\hline $\begin{array}{l}\text { tinggi } \\
\left(\mathrm{B}_{1}\right)\end{array}$ & $\begin{array}{l}\mathrm{n}=15 \\
\Sigma_{\mathrm{A} 1 \mathrm{~B} 1}=289 \\
\Sigma_{\mathrm{A} 1 \mathrm{~B} 1}{ }^{2}=5605 \\
\bar{x}=19,27\end{array}$ & $\begin{array}{l}\mathrm{n}=15 \\
\Sigma_{\mathrm{A} 2 \mathrm{~B} 1}=244 \\
\Sigma_{\mathrm{A} 2 \mathrm{~B} 1}{ }^{2}=4018 \\
\bar{x}=16,27\end{array}$ & $\begin{array}{l}\mathrm{n}=30 \\
\Sigma_{\mathrm{B} 1}=533 \\
\Sigma_{\mathrm{B} 1}=9623 \\
\bar{x}=17,77\end{array}$ \\
\hline $\begin{array}{l}\text { rendah } \\
\left(B_{2}\right)\end{array}$ & $\begin{array}{l}\mathrm{n}=15 \\
\Sigma_{\mathrm{A} 1 \mathrm{~B} 2}=240 \\
\Sigma_{\mathrm{A} 1 \mathrm{~B} 2}=3948 \\
\bar{x}=16\end{array}$ & $\begin{array}{l}\mathrm{n}=15 \\
\Sigma_{\mathrm{A} 2 \mathrm{~B} 2}=283 \\
\Sigma_{\mathrm{A} 2 \mathrm{~B} 2}=5411 \\
\bar{X}=18,87\end{array}$ & $\begin{array}{l}\mathrm{n}=30 \\
\Sigma_{\mathrm{B} 2}=523 \\
\Sigma_{\mathrm{B} 2}=9659 \\
\bar{X}=17,43\end{array}$ \\
\hline $\begin{array}{l}\Sigma \\
\text { Kolom }\end{array}$ & $\begin{array}{l}\mathrm{n}=30 \\
\Sigma_{\mathrm{A} 1}=529 \\
\Sigma_{\mathrm{A} 1}=9553 \\
\bar{x}=17,63\end{array}$ & $\begin{array}{l}\mathrm{n}=30 \\
\Sigma_{\mathrm{A} 2}=527 \\
\Sigma_{\mathrm{A} 2}=9429 \\
\bar{X}=17,67\end{array}$ & $\begin{array}{l}\mathrm{n}=60 \\
\Sigma=1056 \\
\Sigma=18982 \\
\bar{x}=17,60\end{array}$ \\
\hline
\end{tabular}

Pengujian hipotesis dilakukan berdasarkan data yang diperoleh di lapangan. Hasil analisis data dengan menggunakan uji ANAVA dua jalur. Jika terdapat interaksi, maka uji dilanjutkan dengan uji TUKEY dengan maksud untuk menguji hipotesis mengenai efek utama dari kedua variabel bebas yang diteliti.

Tabel 3. Hasil Perhitungan ANAVA Dua Jalur

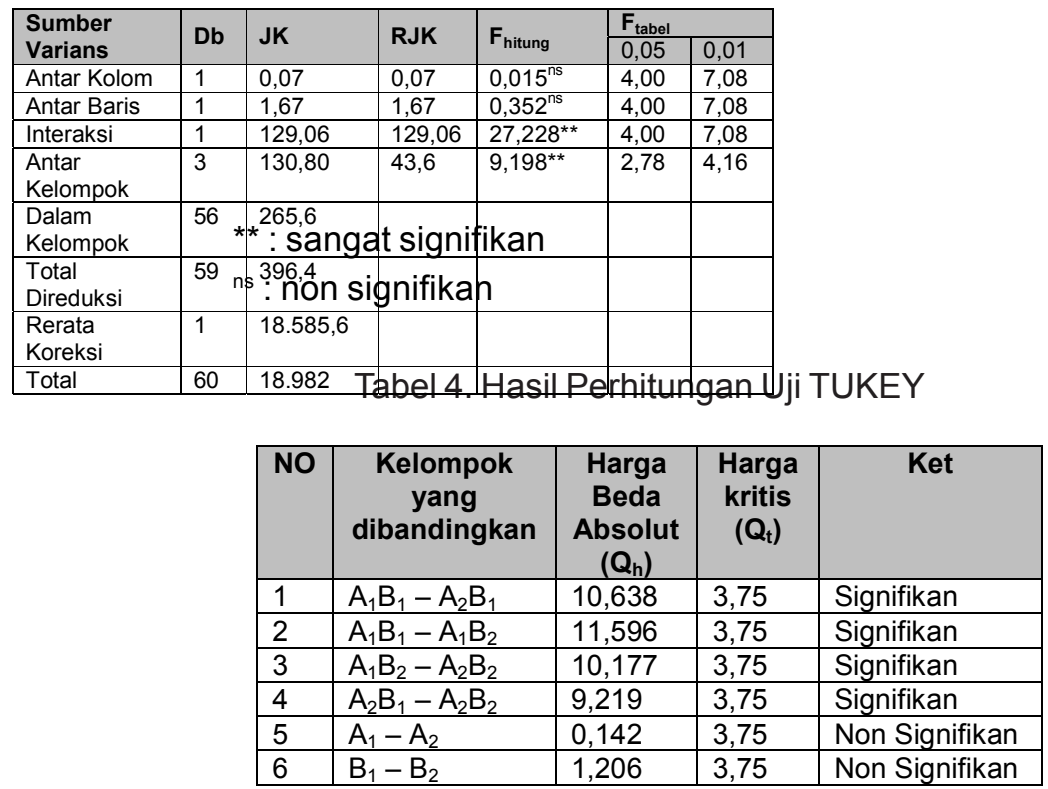

Berdasarkan hasil perhitungan ANAVA dua arah dan uji lanjutan (TUKEY) di atas, maka dapat diuji hipotesis, sebagai berikut.

1. Kecerdasan naturalis anak yang dibelajarkan menggunakan metode pembelajaran dengan praktik langsung lebih tinggi daripada yang menggunakan metode pembelajaran bercerita.

Dari hasil perhitungan ANAVA di atas terlihat bahwa $F_{\text {hitung }}=0,07$ yang ternyata lebih kecil dibandingkan $\mathrm{F}_{\text {tabel }}=4,00(0,07<4,00)$ yang berarti $\mathrm{H}_{0}$ diterima. Berdasarkan hasil tersebut, maka dapat disimpulkan tidak terdapat perbedaan yang signifikan pada skor kecerdasan naturalis anak yang diberikan metode pembelajaran praktik langsung dengan anak yang diberikan metode pembelajaran bercerita.

2. Perbedaan pada skor kecerdasan naturalis anak yang memiliki pengetahuan berwawasan lingkungan yang tinggi. Skor kecerdasan naturalis anak yang diberikan metode pembelajaran melalui praktik langsung lebih tinggi dibandingkan pada skor kecerdasan naturalis anak yang diberikan metode pembelajaran melalui bercerita.

Berdasarkan hasil perhitungan uji TUKEY antara kelompok anak yang dibelajarkan menggunakan metode pembelajaran praktik langsung dan pengetahuan berwawasan lingkungan yang tinggi dengan skor ratarata $=19,27$ dan kelompok anak yang dibelajarkan menggunakan metode pembelajaran bercerita dan pengetahuan berwawasan lingkungan tinggi dengan skor rata-rata $=16,27$. Sedangkan rata-rata kuadrat dalam (RKD) pada ANAVA dua jalur adalah 4,74. sehingga diperoleh selisih nilai rata-rata kelompok $A_{1} B_{1}$ $A_{2} B_{1}=3$ dan nilai harga $Q_{h}=10,638$ dengan $Q_{t}=3,75$. karena $Q_{h}>Q_{t,}$ artinya $H_{0}$ ditolak. Oleh karena itu, maka dapat disimpulkan terdapat perbedaan kecerdasan naturalis anak pengetahuan berwawasan lingkungan yang tinggi yang dibelajarkan menggunakan metode pembelajaran praktik langsung dengan yang dibelajarkan menggunakan metode pembelajaran bercerita.

Sehingga hipotesis penelitian yang menyatakan terdapat perbedaan yang signifikan pada skor kecerdasan naturalis anak yang memiliki pengetahuan berwawasan lingkungan yang tinggi terbukti. Artinya, skor kecerdasan naturalis anak yang diberikan metode pembelajaran melalui praktik langsung lebih tinggi dibandingkan pada skor kecerdasan naturalis anak yang diberikan metode pembelajaran melalui bercerita.

3. Perbedaan pada skor kecerdasan naturalis anak yang memiliki pengetahuan berwawasan lingkungan yang rendah. Skor kecerdasan naturalis anak yang diberikan metode pembelajaran melalui praktik langsung lebih rendah dibandingkan dengan anak yang diberikan metode pembelajaran melalui bercerita.

Dari hasil perhitungan uji TUKEY antara kelompok anak yang dibelajarkan menggunakan praktik langsung dan pengetahuan berwawasan lingkungan yang rendah dengan skor rata-rata = 16 dan kelompok anak yang dibelajarkan menggunakan metode pembelajaran bercerita dan pengetahuan berwawasan lingkungan rendah dengan skor rata-rata $=18,87$. 
Sedangkan rata-rata kuadrat dalam (RKD) pada ANAVA dua jalur adalah 4,74 sehingga diperoleh selisih nilai rata-rata kelompok $A_{1} B_{2}-A_{2} B_{2}=2,87$ dan nilai harga $Q_{h}=10,177$ dengan $Q_{t}=3,75$. karena $Q_{h}>Q_{t}$, artinya $\mathrm{H}_{0}$ ditolak. Berdasarkan hal tersebut, maka dapat disimpulkan terdapat perbedaan kecerdasan naturalis anak berpengetahuan berwawasan lingkungan yang rendah dan dibelajarkan menggunakan metode pembelajaran praktik langsung dengan kecerdasan naturalis anak berpengetahuan berwawasan lingkungan yang rendah dan dibelajarkan menggunakan metode pembelajaran bercerita sehingga hipotesis penelitian yang menyatakan terdapat perbedaan yang signifikan pada skor kecerdasan naturalis anak yang memiliki pengetahuan berwawasan lingkungan yang rendah. Skor kecerdasan naturalis anak yang diberikan metode pembelajaran melalui praktik langsung lebih rendah dibandingkan dengan anak yang diberikan metode pembelajaran melalui bercerita terbukti.

4. Terdapat pengaruh interaksi antara metode pembelajaran dan pengetahuan berwawasan lingkungan anak terhadap kecerdasan naturalis anak.

Hasil perhitungan ANAVA dua jalur menunjukkan bahwa nilai $F_{\text {hitung }}=27,228$ dan $F_{\text {tabel }}=4,00\left(F_{\text {hitung }}>F\right.$ tabel). Hal ini berarti $\mathrm{H}_{0}$ ditolak. Artinya terdapat interaksi yang signifikan antara metode pembelajaran dan pengetahuan berwawasan lingkungan anak terhadap kecerdasan naturalis anak.

Pembahasan hasil penelitian dilakukan berdasarkan deskripsi data kecerdasan naturalis anak dan hasil pengujian hipotesis seperti yang telah dipaparkan sebelumnya, pembahasan hasil pengujian hipotesis penelitian lebih lanjut, adalah sebagai berikut.

1. Hipotesis pertama

Dalam penelitian ditemukan bahwa terdapat perbedaan kecerdasan naturalis antara kelompok anak yang diberi metode pembelajaran praktik langsung dengan kelompok anak yang diberi metode pembelajaran bercerita hal ini dibuktikan dengan uji ANAVA dua jalur diperoleh $F_{\text {hitung }}=9,198>F_{\text {tabel }}=4,16$ yang ternyata signifikan.

Hal ini disebabkan karena metode pembelajaran praktik langsung memberikan kesempatan kepada anak berperan aktif dalam melakukan kegiatan secara langsung. Metode pembelajaran praktik langsung menitikberatkan peran aktif anak sehingga anak memiliki dan memahami tentang lingkungan dan mampu membuat klasifikasi flora fauna dan benda-benda alamnya serta memiliki kepekaan tentang kondisi alam dan lingkungan. Selama ini, di dalam pembelajaran yang dilaksanakan di TKAr-Ridho hanya memanfaatkan apa yang ada sebagai sumber pembelajaran dan peran aktif anak dalam mengeksplorasi lingkungan belum maksimal.

Cara belajar yang lebih menekankan peran anak secara aktif menyebabkan pengetahuan yang diperoleh anak dapat lebih dipahami dan bertahan lama sehingga kecerdasan naturalius anak dapat diaplikasikan pada kehidupan sehari-hari dengan lebih baik. Dengan demikian, metode pembelajaran praktik langsung lebih efektif dibandingkan dengan strategi pembelajaran bercerita dalam meningkatkan kecerdasan naturalis anak.

\section{Hipotesis kedua}

Hipotesis penelitian yang menyatakan bahwa kecerdasan naturalis pada kelompok anak yang memiliki pengetahuan berwawasan lingkungan tinggi yang diberikan metode pembelajaran praktik langsung lebih tinggi daripada kelompok anak yang diberikan metode pembelajaran bercerita dapat diterima, hal ini dapat dilihat pada besarnya rerata skor kecerdasan naturalis pada kelompok anak yang memiliki pengetahuan berwawasan lingkungan tinggi yang diberikan metode pembelajaran praktik langsung lebih tinggi secara signifikan dibandingkan dengan kelompok anak yang memiliki pengetahuan berwawasan lingkungan tinggi yang diberikan metode pembelajaran bercerita.

Pada metode pembelajaran praktik langsung, setelah guru memberikan materi dan mendemonstrasikannya, siswa dituntut untuk melakukan materi yang telah dilihatnya untuk dapat memecahkan suatu masalah, metode ini dapat efektif jika anak memiliki pengetahuan berwawasan yang tinggi dan diberikan metode pembelajaran yang tepat, maka akan memberikan pemahaman yang lebih bermakna, pada kecerdasan naturalis anak. Dale juga menjelaskan bahwa pemberian metode pembelajaran dengan menggunakan model, melakukan simulasi, serta melakukan praktik langsung akan memberikan banyak pengalaman belajar bagi anak. Anak tidak hanya belajar menemukan sesuatu, tetapi anak juga memiliki kemampuan untuk menganalisis apa yang telah ditemukannya. Kemampuan ini hanya akan diperoleh jika dapat berinteraksi langsung dengan lingkungannya. Berbeda ketika belajar hanya dengan mendengarkan atau melihat saja.

Pengembangan kecerdasan naturalis anak, pelaksanaannya memerlukan tiga kombinasi yang berupa pengetahuan, sikap, serta keterampilan dalam memahami dan menggunakan kecakapan saat berinteraksi dengan lingkungan.

3. Hipotesis ketiga

Hipotesis ketiga yang menyatakan bahwa 
kecerdasan naturalis anak pada kelompok anak yang memiliki pengetahuan berwawasan rendah yang diberikan metode pembelajaran bercerita lebih tinggi daripada kelompok anak yang diberikan metode pembelajaran praktik langsung dapat diterima, hal ini dapat dilihat pada besarnya rerata skor kecerdasan naturalis pada kelompok anak yang memilik pengetahuan berwawasan lingkungan rendah yang diberikan metode pembelajaran bercerita lebih tinggi secara signifikan dibanding dengan kelompok anak yang memiliki pengetahuan berwawasan lingkungan rendah, yang diberikan metode pembelajaran bercerita.

Pada metode pembelajaran bercerita, peran guru lebih aktif dibandingkan anak. Pada metode pembelajaran ini, anak tidak terlalu dituntut aktif, anak hanya berinteraksi berdasarkan cerita yang disajikan oleh guru. Selain itu juga pada metode ini, kemampuan anak dalam mendengarkan lebih banyak dibandingkan dengan visualnya, adakalanya ketika guru tidak ekspresif dalam bercerita akan membuat anak tidak tertarik dengan cerita dan akan terkesan lebih membosankan bagi anak-anak yang cenderung aktif. Berdasarkan kesesuaian tersebut, maka siswa yang memiliki pengetahuan berwawasan lingkungan rendah, kecerdasan naturalisnya akan lebih baik jika diberikan pembelajaran dengan metode pembelajaran bercerita 4. Hipotesis keempat
Hipotesis keempat yang menyatakan bahwa terdapat interaksi antara metode pembelajaran dengan pengetahuan berwawasan lingkungan terbukti, yakni dengan didapat $F_{\text {hitung }}=27,228$ lebih besar dari $F_{\text {tabel }}$ $=7,08$. Dengan demikian, pemberian metode pembelajaran harus memperhatikan tingkat kecerdasan naturalis anak.

Anak yang memiliki tingkat kecerdasan naturalis tinggi yang diberikan metode pembelajaran praktik langsung menunjukkan kecerdasan naturalis yang lebih tinggi daripada anak yang diberikan metode pembelajaran bercerita. Sebaliknya, anak yang memiliki tingkat kecerdasan naturalis rendah yang diberikan metode pembelajaran praktik langsung menunjukkan kecerdasan naturalis yang lebih rendah daripada anak yang diberikan metode pembelajaran bercerita. Hal ini menunjukkan bahwa pemberian metode pembelajaran dapat mempengaruhi interaksi dalam kegiatan pembelajaran. Selain itu juga, dalam memberikan metode pembelajaran harus memperhatikan tingkat pengetahuan yang dimiliki oleh anak, dalam hal ini pengetahuan berwawasan lingkungannya, sehingga pemberian metode yang tepat sesuai dengan tingkat pengetahuan berwawasan lingkungannya akan memberikan perkembangan yang optimal pada kecerdasan naturalis anak.

KESIMPULAN

\section{Kesimpulan}

Penelitian ini mengkaji pengaruh metode pembelajaran langsung terhadap tingkat kecerdasan naturalis anak usia 5-6 tahun, metode pembelajaran yang diberikan berupa metode pembelajaran praktik langsung dan metode pembelajaran bercerita. Berdasarkan hasil uji coba, hipotesis yang telah diuraikan pada bab sebelumnya dapat ditarik kesimpulan, sebagai berikut.

Pertama, kecerdasan naturalis anak yang diberi metode pembelajaran langsung lebih tinggi daripada anak yang diberi metode pembelajaran bercerita. Dari gambaran ini dapat dikatakan bahwa untuk meningkatkan kecerdasan naturalis anak usia 5-6 tahun dapat digunakan metode pembelajaran praktik langsung.

Kedua, kecerdasan naturalis anak yang diberi metode pembelajaran praktik langsung pada kelompok anak yang memiliki pengetahuan berwawasan lingkungan tinggi lebih tinggi daripada kelompok anak yang diberi metode pembelajaran bercerita. Dengan demikian, untuk meningkatkan kecerdasan naturalis anak usia 5-6 tahun yang memiliki tingkat kecerdasan naturalis tinggi dapat menggunakan metode pembelajaran praktik langsung.

Ketiga, kecerdasan naturalis anak yang diberi metode pembelajaran bercerita pada kelompok anak yang memiliki pengetahuan berwawasan lingkungan rendah lebih tinggi daripada kelompok anak yang diberi metode pembelajaran praktik langsung. Dengan demikian, untuk meningkatkan kecerdasan naturalis anak usia 5-6 tahun yang memiliki pengetahuan berwawasan lingkungan rendah dapat digunakan metode pembelajaran bercerita.

Keempat, terdapat interaksi antara metode pembelajaran dan pengetahuan berwawasan lingkungan terhadap kecerdasan naturalis anak usia 5-6 tahun. Dapat disimpulkan bahwa untuk meningkatkan kecerdasan natural anak usia 5-6 tahun dapat menggunakan metode pembelajaran praktik langsung dan bercerita.

\section{Saran}

Berdasarkan kesimpulan dan implikasi penelitian 
di atas, maka dapat dikemukakan beberapa saran atas temuan penelitian ini, sebagai berikut.

Pertama, bagi pendidik dan guru TK dalam upaya meningkatkan kecerdasan naturalis anak usia 5-6 tahun hendaknya dapat menggunakan metode pembelajaran yang tepat. Guru hendaknya dapat mengembangkan metode pembelajaran melalui kegiatan-kegiatan yang bervariasi dan menyenangkan bagi anak. Dalam menentukan metode pembelajaran yang akan digunakan hendaknya guru juga mengetahui dan memperhatikan pengetahuan berwawasan lingkungan anak.

Kedua, bagi pengelola TK, hendaknya dapat memberikan kesempatan pada guru untuk mengembangkan metode pembelajaran yang digunakan sehingga kegiatan-kegiatan yang dilakukan dapat bervariasi dan menarik bagi anak.

Ketiga, bagi orang tua, dapat memberikan stimulasi yang mengembangkan pengetahuan berwawasan lingkungan anak melalui aplikasi kegiatan sehari-hari di rumah melalui pembiasaan-pembiasaan positif yang berkaitan dengan cara anak mengenal, menjaga diri, dan lingkungannya, sehingga pengembangan kecerdasan naturalis anak dapat lebih optimal lagi.

Keempat, bagi masyarakat, memberikan kesempatan bagi anak untuk dapat menikmati lingkungannya sebagai bagian dari lingkungan pendidikan yang aman dan nyaman, sehingga dapat bereksplorasi di lingkungan tempat tinggal agar pengetahuan berwawasan lingkungan menjadi lebih baik yang menjadi landasan untuk meningkatkan kecerdasan naturalisnya.

Kelima, bagi peneliti pendidikan anak usia dini selanjutnya, mungkinnya dapat mengembangkan penelitian ini dengan meneliti faktor-faktor lain yang belum diteliti pada penelitian ini. Dalam hal ini, masih banyak faktor-faktor lain yang dapat mempengaruhi kecerdasan naturalis anak, seperti faktor sosial ekonomi orang tua atau faktor usia.

\section{DAFTAR PUSTAKA}

Anderson, M. (2002). The development of intelegences. East Sussex: Psychology Press, Ltd.

Christison, M. A. (1999). Multiple intelligences: Theory and practice in adult ESL. Diakses pada tanggal 1 Juni 2010 dari http://www.cal.org/ncle/digest/ mi.htm.

Cooper, R. K. \& Sawat, A. (1998). Excelent EQ: Kecerdasan emosional dalam kepemimpinan dan organisasi. (Alex Tri, penerjemah). Jakarta: Gramedia.

Cripps, A \& Nguyen, N. (2004). Using multiple intelligences for effective online teaching. Diakses pada tanggal 1 Juni 2010 dari http:// www.nssa.apsu.edu.

Gay, L. R. (1996). Educational research competencies for analysis and application. (Fifth edition). New Jersey: Imprint of Hall.

Good, L. T. \& Brophy, J.E. (1990). Educational psychology : A realistic approach. (Fourth edition). New York : Longman.

Gottlieb, D. L. (1995). Environment and design in housing. New York : The Mc. Millan Company.

Haryanto. (1997). Perencanaan pengajaran. Jakarta: Rineka Cipta.

Neomatahari. (2010). Mengenalkan pendidikan lingkungan hidup di sekolah. Diakses pada tanggal 1 Juni 2010 dari http://neomatahari.blogspot.com/2010/04/mengenalkan-pendidikan- lingkungan-hidup.html.

Nerney, Mc. D. \& Nerney, Mc. V. (1998). Educational psychology. Sidney: Prentice Hall Australia Pty. Ltd.

Porter, B. D., Readon, M., \& Nourie, S. (2002). Quantum teaching. (Ary Nilandary, penerjemah). Bandung: Kaifa.

Ross, C. \& Nicholl, M. C. J. (2002). Accelerated learning for the $21^{\text {st }}$ century. (Dedy Ahimsa, penerjemah). Bandung: Nuansa.

Salim, E. (1993). Lingkungan hidup dan pembangunan. Jakarta : Mutiara Sumber Widya.

Sawyer, W. E. \& Corner, D. E. (1991). Growing up with literature. Washington: Delmar Publisher.

Semiawan, C. R. (2002). Belajar dan pembelajaran dalam tahap usia dini. Jakarta: PT Prenhallindo.

Semiawan, C. R. \& Djeniah, A. (2002). Petunjuk layanan dan pembinaan kecerdasan siswa. Bandung: Remaja Rosdakarya.

Soekamto, S. (1982). Sosiologi suatu pengantar. Jakarta : UI - Press.

Soekamto, T. \& Saripusin, W.U. (1997). Teori belajar dan metode-metode pembelajaran. Jakarta: PTUPPAI UT.

Soeryani, M. (2002). Ekologi manusia. Jakarta : Pusat Penerbit Universitas Terbuka.

Sprinthall, A. N. \& Sprinthall, C.R. (1990). Educational psychology: A developmental approach. New 
York : McGraw. Hill, Inc.

Sudjana, D. S. (1997). Metode dan teknik pembelajaran partisipatif. Bandung: Falah Production.

Sujiono, Y. N., dkk. (2004). Metode pengembangan kognitif. Jakarta: Pusat Penerbitan Universitas Terbuka.
Sujiono, Y. N. (2009). Konsep dasar pendidikan anak usia dini. Jakarta : PT Indeks.

Whiterington, H. C. (2002). Psikologi pendidikan. (Fudyarto, penerjemah). Yogyakarta: Global Pustaka Utama. 